\title{
Evaluation of a Test Kit for the Rapid and Simple Colorimetric Measurement of Angiotensin I-Converting Enzyme in Serum
}

\author{
By F. Boomsma and M. A. D. H. Schalekamp \\ Department of Internal Medicine I, University Hospital Dijkzigt, Rotterdam, The Netherlands
}

(Received June 13, 1983)

Summary: We have evaluated a recently introduced colour test kit for the determination of serum angiotensin I-converting enzyme catalytic activity. $p$-Hydroxyhippuric acid, liberated from $p$-hydroxyhippuryl- $L$-histidyl- $L$-leucine by angiotensin I-converting enzyme, is converted into a quinoneimine dye with an absorption maximum at $505 \mathrm{~nm}$. The procedure shows excellent linearity over the whole range of catalytic activities found in serum. Intra- and inter-assay coefficients of variation are $2-5$ and $7-10 \%$ respectively. Correlation with a modified Cushman-Cheung ((1971) Biochem. Pharmacol. 20,1637-1648) method currently used in our laboratory is good, with $r=0.985$ and a regression equation of y (colour kit) $=0.423 \times$ (CushmanCheung $)+0.765$. Haemoglobin, lipids, bilirubin and prednisone do not interfere but uric acid in concentrations higher than $600 \mu \mathrm{mol} / 1$ does. No extraction step is required. The assay is very rapid, and more than twenty samples can be determined in an hour.

\section{Bewertende Prüfung eines Testbestecks zur schnellen und einfachen kolorimetrischen Bestimmung von Angiotensin I-Converting Enzyme im Serum}

Zusammenfassung: Wị prüften einen kürzlich eingeführten Farbtest zur Bestimmung der katalytischen Konzentration von Angiotensin I-Converting Enzyme im Serum. p-Hydroxyhippursäure wird durch das Enzyme aus $p$-Hydroxyhippuryl- $L$-histidyl- $L$-leucin freigesetzt und zu einem Chinoniminfarbstoff mit einem Absorptionsmaximum bei $505 \mathrm{~nm}$ umgesetzt. Das Verfahren zeigt über den gesamten im Serum vorkommenden Bereich katalytischer Konzentration ausgezeichnete Linearität. Die Variationskoeffizienten betrugen 2-5\% in der Serie und 7-10\% von Tag zu Tag. Die Korrelation mit einer in unserem Laboratorium laufend gebrauchten modifizierten Methode nach Cushman \& Cheung ((1971) Biochem. Pharmakol. 20,1637-1648) ist mit $\mathrm{r}=0,985$ und einer Regressionsgleichung von $\mathrm{y}$ (Farbtest) $=0,423 \times$ (Cushman-Cheung-Methode) + 0,765 gut. Hämoglobin, Lipide, Bilirubin und Prednison stören die Methode nicht, wohl aber Harnsäure in Konzentrationen $>600 \mu \mathrm{mol} / 1$. Ein Extraktionsschritt ist nicht erforderlich. Die Methode ist sehr schnell, mehr als 20 Proben können in einer Stunde bestimmt werden.

\section{Introduction}

Determination of the serum catalytic activity of angiotensin I-converting enzyme (EC 3.4.15.1) is increasingly being used as a valuable tool in the diagnosis and management of sarcoidosis (1-4) and certain other diseases such as silicosis (5), asbestosis (5), Gaucher's disease (6) and, possibly, malignant histiocytosis $(7,8)$. Serum angiotensin I-converting enzyme is elevated in the active stages of these diseases, as it is in hyperthyroidism (9), in chronic liver disease (10), and in diabetes mellitus with severe retinopathy (11). In contrast, serum angiotensin I-converting enzyme is depressed in patients with malignant lymphomas (12), leukaemia (12), multiple myeloma (12) and lung cancer (13). 
Many methods for determining angiotensin I-converting enzyme have been described in the literature, most of them based on the enzymatic cleavage of the tripeptide substrates hippuryl- $L$-histidyl- $L$-leucine or hippuryl-glycyl-glycine. Quantitation of one of the cleavage products, hippuric acid or the dipeptide, has been achieved in a wide variety of ways: spectrophotometric $(14,15)$, fluorimetric $(16,17)$, radioisotopic (18), colorimetric (19-21), or by HPLC (2123). In most assays, a time-consuming extraction procedure is required. Recently, a diagnostic kit has been introduced by the Fujizoki Pharmaceutical Co, Tokyo, Japan, based on the colorimetric assay reported by Kasahara \& Ashihara (19). In this method, $p$-hydroxyhippuric acid is cleaved by angiotensin I-converting enzyme from the substrate $p$-hydroxyhippuryl- $L$-histidyl- $L$-leucine and converted into $p$-hydroxybenzoic acid by the enzyme hippuricase. Reaction with sodium periodate and 4-aminoantipyrine then yields a quinoneimine dye with an absorption maximum at $505 \mathrm{~nm}$. No extraction step is necessary, and the absorbance can be read within minutes of stopping the incubation.

We have evaluated the performance of this angiotensin I-converting enzyme colour kit and compared it with the modified Cushman-Cheung method (15), which has been used in this laboratory for the last few years.

\section{Materials and Methods}

Test kit, chemicals

Angiotensin I-converting enzyme colour kits (Fujizoki Pharmaceutical Co, Tokyo, Japan) were a gift from Gist-Brocades Pharmaca Nederland BV, Rijswijk, The Netherlands. One package contained four reagents:

1) 1 vial with $24 \mathrm{ml}$ of buffer solution $(0.12 \mathrm{~mol} / \mathrm{l}$ boric acid, 0.7 $\mathrm{mol} / \mathrm{l}$ sodium chloride, $\mathrm{pH} 8.3$ );

2) 2 vials of lyophilized substrate, which, after reconstitution with $11 \mathrm{ml}$ of buffer solution each, contained $10 \mathrm{mmol} / \mathrm{l} p$-hydroxyhippuryl- $L$-histidyl-L-leucine, $2.5 \mathrm{mmol} / \mathrm{l}$ 4-aminoantipyrine and 3 $\mathrm{kU} / \mathrm{h}$ hippuricase;

3) 2 vials of stopper solution ( $31 \mathrm{ml}$ each) containing $3 \mathrm{mmol} / \mathrm{h}$ disodium ethylenediaminetetraacetate and $2 \mathrm{~g} / \mathrm{T}$ Triton X-100; and

4) 2 vials of lyophilized developer, each containing $6.5 \mathrm{mmol} / \mathrm{l}$ sodium periodate after reconstitution with $31 \mathrm{ml}$ of stopper solution.

Hippuryl- $L$-histidyl- $L$-leucine was obtained from Sigma, St. Louis, USA.

\section{Procedures}

In the procedure recommended by the manufacturer, $0.5 \mathrm{ml}$ of the substrate solution is added to $0.1 \mathrm{ml}$ of sample serum in a test tube. The tube is mixed and incubated at $37^{\circ} \mathrm{C}$ for 20 minutes.
Then $1.5 \mathrm{ml}$ of the stopper/developer solution is added, and after mixing and incubating at $37^{\circ} \mathrm{C}$ for 3 minutes, the absorbance is read at $505 \mathrm{~nm}$ against distilled water. Blanks are prepared by adding the sample serum after the 20 minutes incubation step.

We have modified this procedure in three ways:

1) By halving the amounts of serum and reagents used and employing semimicrocuvettes, twice as many samples can be assayed with one package.

2) The method of preparing blanks by adding serum after the incubation step is rather inconvenient. We prepared blannks by pipetting serum in all test tubes at the same time, and by adding 10 $\mu \mathrm{l}$ of a disodium ethylenediaminetetraacetate solution (104 $\mathrm{mg}$ in $10 \mathrm{ml}$ of $0.15 \mathrm{~mol} / \mathrm{NaCl}$, brought to $\mathrm{pH} 8.3$ with $1 \mathrm{~mol} / / \mathrm{NaOH}$ ) to the tubes for the blanks. For 17 samples, blanks were prepared according to the manufacturer and by our own method. Blañk absorbance (mean $\pm \mathrm{SEM}$ ) was $0.061 \pm 0.015$ and $0.067 \pm 0.022$ respectively, while calculated angiotensin I-converting enzyme catalytic activity (mean $\pm S D$ ) was $32.1 \pm 22.8$ vs. $31.6 \pm 22.4$ $\mu \mathrm{mol} / \mathrm{min} \cdot 1$ of $p$-hydroxyhippuric acid liberated.

3) To allow for the processing of a larger number of samples in the same batch, we lengthened the incubation time to 30 minutes, with the added advantage of a higher sample absorbance.

For the evaluation of the kit we thus used the following procedure: serum $(50 \mu \mathrm{l})$ was pipetted into the test tubes; to the tubes for the blanks were added $10 \mu \mathrm{l}$ of a disodium ethylenediaminetetraacetate solution (final concentration in the incubation mixture $1 \mathrm{mmol} / \mathrm{l})$. Substrate solution $(250 \mu \mathrm{l})$ was added, and the tubes were mixed and incubated at $37^{\circ} \mathrm{C}$ for 30 minutes. After adding $750 \mu \mathrm{l}$ of the stopper/developer solution, followed by mixing and incubating for 3 minutes at $37^{\circ} \mathrm{C}$, the absorbance was read at 505 $\mathrm{nm}$. Samples were measured in duplicate.

\section{Calculation:}

Angiotensin I-converting enzyme ( $p$-hydroxyhippuric acid, $\mu \mathrm{mol} /$ $\min \cdot 1=U / 1)=$

$$
\frac{A_{\text {sample }}-A_{\text {blank }}}{12000} \times \frac{1.05}{0.05} \times \frac{1}{30} \times 10^{6}
$$

\section{Results}

\section{Linearity}

Three sera were incubated for various time intervals as indicated in figure 1 . Formation of $p$-hydroxyhippuric acid was found to be linear up to $130 \mathrm{nmol}$, corresponding to a conversion of $5.2 \%$ of the substrate. With an incubation time of $30 \mathrm{~min}$ and a sample portion of $50 \mu \mathrm{l}$, the assay would thus be linear up to an angiotensin I-converting enzyme catalytic activity of $85 \mathrm{U} / \mathrm{l}$. This was borne out in an experiment in which three sera with increasing angiotensin I-converting enzyme catalytic activity were assayed undiluted and in various dilutions with $0.15 \mathrm{~mol} / \mathrm{l}$ $\mathrm{NaCl}$ (fig. 2). Linearity was excellent, even for the serum with the highest catalytic activity (84.6 U/, the highest we have ever encounitered). 


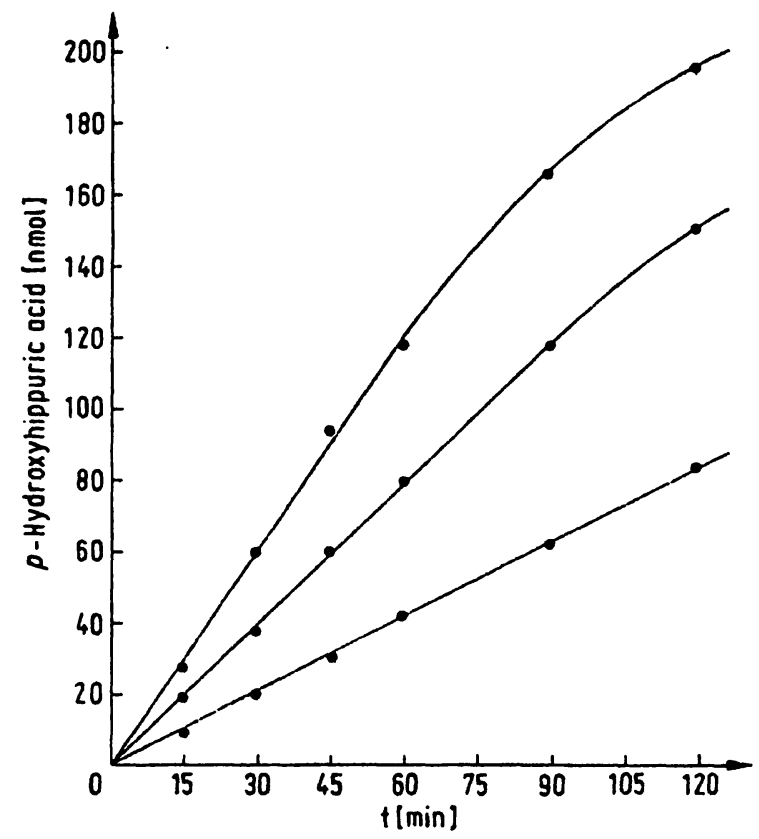

Fig. 1. Formation of $p$-hydroxyhippuric acid vs. incubation time in three different sera.

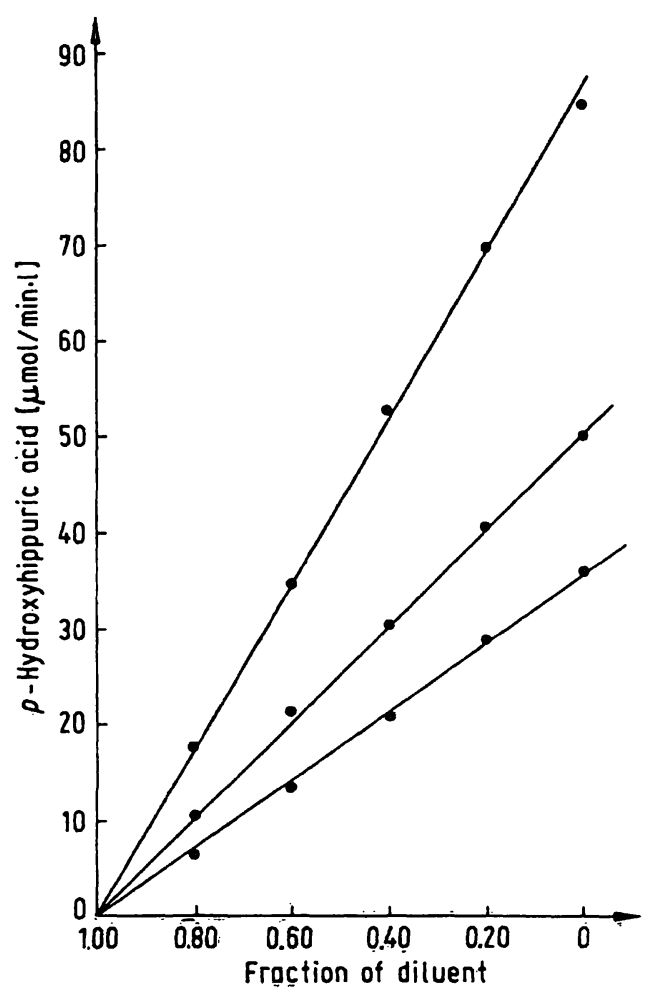

Fig. 2. Linear relationship between measured angiotensin I-converting enzyme catalytic activity and serum dilution in three different sera. Dilution is expressed as fraction of $0.15 \mathrm{~mol} / \mathrm{h} \mathrm{NaCl}$ in mixtures of serum and $0.15 \mathrm{~mol} / \mathrm{l}$ $\mathrm{NaCl}$.

\section{Precision}

Sera with low, medium and high angiotensin I-converting enzyme catalytic activity were used for determining both within-run and between-run variability. Reproducibility was good, as can be seen in table 1 .
Tab. 1. Variability of the angiotensin l-converting enzyme colour test kit.

\begin{tabular}{|c|c|c|c|c|c|}
\hline & Sample & $n$ & $\begin{array}{l}\bar{x} \\
(U / I)\end{array}$ & $\begin{array}{l}S D \\
(U / 1)\end{array}$ & $\begin{array}{l}\text { CV } \\
(\%)\end{array}$ \\
\hline \multirow[t]{3}{*}{ Within-run } & A & 6 & 9.2 & 0.5 & 5.3 \\
\hline & B & 6 & 20.1 & 0.7 & 3.7 \\
\hline & $\bar{C}$ & 6 & 37.6 & 0.9 & 2.3 \\
\hline \multirow[t]{4}{*}{ Between-run } & $D$ & 4 & 9.4 & 0.9 & 9.3 \\
\hline & $\mathrm{E}$ & 4 & 13.9 & 1.2 & 8.5 \\
\hline & $\mathrm{F}$ & 13 & 18.3 & 1.9 & 10.3 \\
\hline & G & 7 & 36.1 & 2.6 & 7.3 \\
\hline
\end{tabular}

In a series of 80 duplicate measurements (mean angiotensin I-converting enzyme $29.7 \mathrm{U} / \mathrm{l}$ ) the standard deviation of the differences between duplicates was $2.0 \mathrm{U} / 1$. In our opinion it is thus not necessary to measure samples in duplicate. We recommend that sera are briefly centrifuged before use, as pipetting of turbid sera is probably one of the main causes of measurement errors.

\section{Comparison with the modified Cushman-Cheung} method

Angiotensin I-converting enzyme was determined in 71 samples with the colour kit as well as by the modified Cushman-Cheung method. An excellent correlation was found between the two methods, with $r=$ 0.985 (fig. 3). The regression line, calculated by the least-squares method, was: $y$ (colour kit) $=0.423 x$ (Cushman-Cheung) +0.765 , with standard error of

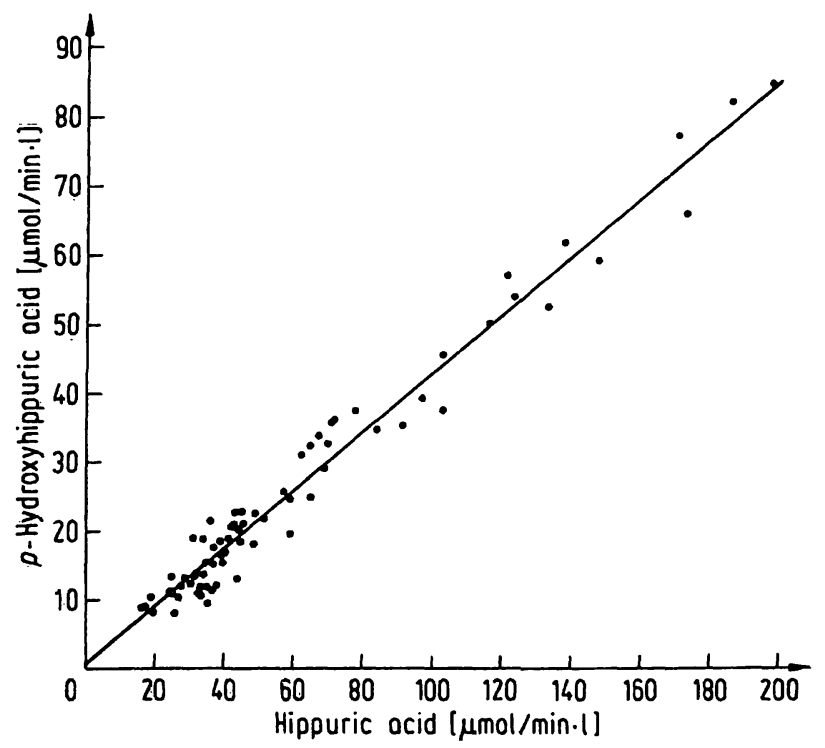

Fig. 3. Comparison of the coluur test kit (ordinate) with the modified Cushman-Cheung method (abscissa). 
the estimate $S_{y . x}=2.35$ and standard deviation of the slope $S_{b_{y, x}}=0.0065$. The Deming regression line (24) was nearly identical: $y$ (colour kit) $=0.429 x$ (Cushman-Cheung) +0.413 . The normal range with the colour kit is $7-20 \mu \mathrm{mol} / \mathrm{min} \cdot 1$ of $p$-hydroxyhippuric acid $(15-45 \mu \mathrm{mol} / \mathrm{min} \cdot 1$ of hippuric acid with the modified Cushman-Cheung method).

\section{Interference}

Haemolytic sera, lipaemic sera, and sera with a high bilirubin content were investigated and found not to interfere in the determination of angiotensin I-converting enzyme: results fitted the regression line with the Cushman-Cheung method, and straight lines were obtained when the samples were assayed after dilution with $0.15 \mathrm{~mol} / 1 \mathrm{NaCl}$. Blank absorbances were higher than with normal sera $(0.1-0.3)$. Uric acid does interfere; when the uric acid concentration of three normal sera $(<0.6 \mathrm{mmol} / \mathrm{l})$ was increased by $0.6,1.5,3.0$ and $6.0 \mathrm{mmol} / \mathrm{l}$, the measured catalytic activity decreased by $5,12,15$ and $21 \%$ respectively, compared with the non-enriched sera.

Addition of various amounts of prednisone, up to $1.4 \mathrm{mmol} / \mathrm{l}$, did not change the measured angiotensin I-converting enzyme value of serum.

\section{Colour stability}

The angiotensin I-converting enzyme catalytic activity of seven sera was calculated from the absorbance measured immediately after the 3-min incubation step with the stopper/developer solution, and subsequently from the absorbance measured after various times at room temperature or at $4{ }^{\circ} \mathrm{C}$. Results, expressed as the fraction of the activity calculated from the immediately measured absorbance, are shown in table 2 .

Tab. 2. Colour stability of the reaction mixture. Results are expressed as the fraction of the catalytic activity calculated from the immediately measured absorbance.

\begin{tabular}{llllllllll}
\hline $\begin{array}{l}\text { Reaction } \\
\text { mixture } \\
\text { kept: }\end{array}$ & \multicolumn{1}{l}{ at room tempeature for } & \multicolumn{4}{l}{ at $4{ }^{\circ} \mathrm{C}$ for } \\
& $1 \mathrm{~h}$ & $2 \mathrm{~h}$ & $4 \mathrm{~h}$ & $24 \mathrm{~h}$ & $5 \mathrm{~h}$ & $24 \mathrm{~h}$ & $72 \mathrm{~h}$ \\
\hline & & & & & & & & \\
\hline Fraction, & & & & & & & & \\
$\bar{x}$ & 1.00 & 1.00 & 0.99 & 0.87 & 0.98 & 0.99 & 0.94 \\
SD & 0.015 & 0.017 & 0.026 & 0.041 & 0.016 & 0.023 & 0.116 \\
\hline
\end{tabular}

Measurement of unblocked and total angiotensin Iconverting enzyme catalytic activity after captopril

Angiotensin I-converting enzyme can be blocked by the converting enzyme inhibitor captopril (Capoten ${ }^{\circledR}$ ), a new antihypertensive drug. We have previously reported that the angiotensin I-converting enzyme inhibition can be rapidly reversed in vitro by the addition of $\mathrm{N}$-ethylmaleimide to the incubation mixture for the Cushman-Cheung method (final conncentration $0.1 \mathrm{mmol} / \mathrm{l})$, thus allowing the measurement of total, i.e. blocked and unblocked angiotensin I-converting enzyme catalytic activity (15). To see whether the same holds for the colour kit, we added captopril $(5 \mu \mathrm{g})$ to $1.5 \mathrm{ml}$ of four sera. Angiotensin I-converting enzyme catalytic activity was then determined in this plasma, and also after the addition of various amounts of $\mathrm{N}$-ethylmaleimide to the incubation mixture. Results are shown in figure 4. The addition of captopril reduced the measured catalytic activity to 0.06 of the original catalytic activity, while addition of $\mathrm{N}$-ethylmaleimide in final concentrations of $0.1,0.25,0.5,0.75$ and $1.0 \mathrm{mmol} / \mathrm{l}$ resulted in a restoration to $0.68,0.88,0.78,0.66$ and 0.50 respectively of the original catalytic activity. The decrease in reversal of inhibition with higher concentrations of $\mathrm{N}$-ethylmaleimide, which contrasts with the increase seen with the Cushman-Cheung method, is probably caused by interference of $\mathrm{N}$ ethylmaleimide with hippuricase.

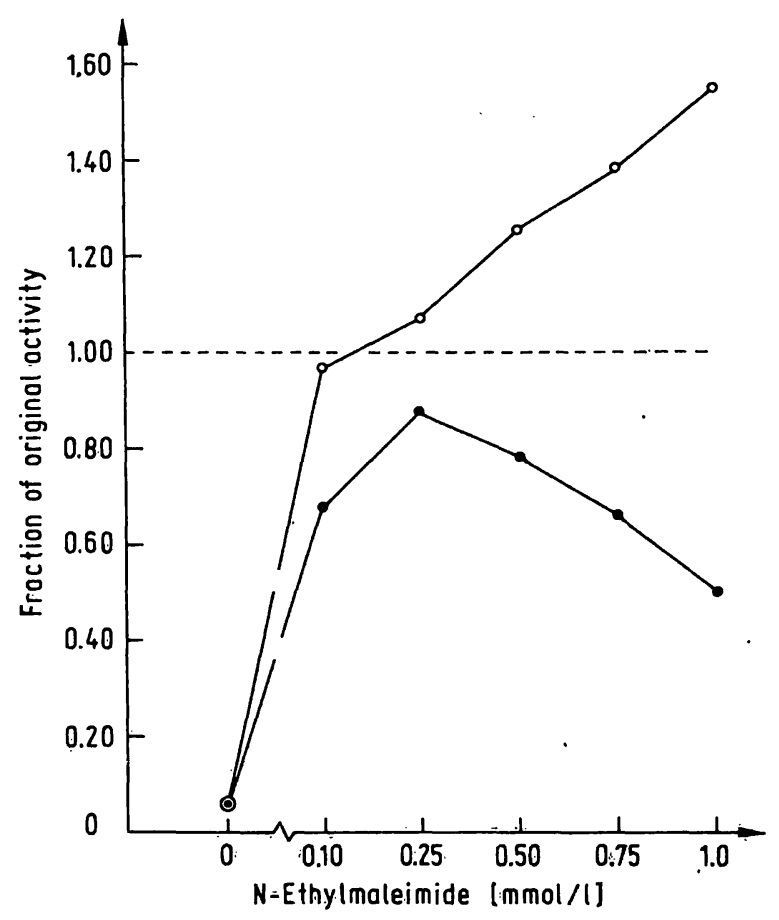

Fig. 4. Influence of $\mathrm{N}$-ethylmaleimide on measured angiotensin I-converting enzyme catalytic activity in serum containing captopril.

$O$ measured by the modified Cushman-Cheung method - measured by the Fujizoki method Points are means of four experimients. 


\section{Discussion}

In contrast to the Cushman-Cheung method, the colour kit shows excellent linearity over the whole range of angiotensin I-converting enzyme catalytic activities likely to be encountered in serum. This difference can, at least partly, be attributed to the lower $\mathrm{V}_{\max }$ of the reaction of angiotensin I-converting enzyme with $p$-hydroxyhippuryl- $L$-histidyl- $L$-leucine as compared with hippuryl- $L$-histidyl- $L$-leucine (19), resulting in a lower rate of hydrolysis with the colour kit than with methods employing hippuryl- $L$ histidyl- $L$-leucine. It is of interest to note the difference in chloride dependency. With hippuryl- $L$-histidyl- $L$-leucine, the optimal chloride concentration in the incubation mixture is $0.3 \mathrm{~mol} / \mathrm{/}(14)$, whereas in the colour kit, using $p$-hydroxyhippuryl- $L$-histid$y l-L$-leucine as a substrate, the optimal concentration of chloride is $0.58 \mathrm{~mol} / \mathrm{l}(25)$.

The lower rate of hydrolysis makes the colour kit less sensitive than some other methods described in the literature, but this is hardly a disadvantage, since the sensitivity is adequate for measuring angiotensin Iconverting enzyme in serum. The sensitivity might become a limiting factor only when precise measurements are needed in fluids other than serum, with much lower angiotensin I-converting enzyme catalytic activity, or in sera containing converting enzyme inhibitors. In these cases, however, the sensitivity of the colour kit can be enhanced by modifying the procedure, e.g. by a longer incubation time or by using a larger volume of the sample.

The precision of the assay is good. Both serum and heparinized plasma can be used, as in the CushmanCheung method. Only uric acid in abnormally high concentrations was found to interfere.

The method for measuring total angiotensin I-converting enzyme catalytic activity in sera of patients treated with captopril is not fully applicable when using the colour kit. Nearly 0.90 of the total activity is measured, however, when $\mathrm{N}$-ethylmaleimide is present in the incubation mixture in a concentration of $0.25 \mathrm{mmol} / \mathrm{l}$. This is adequate if one just wants to check 'patient compliance'.

In conclusion, we find the colour kit to be a simple, reliable and rapid method for determining serum angiotensin I-converting enzyme catalytic activity. Twenty or more samples can be measured in an hour. No extraction procedure is necessary, and only a simple spectrophotometer is required.

\section{References}

1. Lieberman, J. (1975) Am. J. Med. 59, 365-372.

2. Ueda, E., Kawabe, T., Tachibana, T. \& Kokubu, T. (1980) Am. Rev. Resp. Dis. 121, 667-671.

3. De Remee, R. A. \& Rohrbach, M. S. (1980) Ann. Intern. Med. 92, 361-365.

4. Boomsma, F., Tan, K. Y. \& Schalekamp, M. A. D. H. (1981) Neth. J. Med. 24, 169-174.

5. Grönhagen-Riska, C., Kurppa, K., Fyhrquist, F. \& Selroos, O. (1978) Scan. J. Respir. Dis. 59, 228-231.

6. Lieberman, J. \& Beutler, E. (1976) N. Engl. J. Med. 294, $1442-1444$.

7. Grönhagen-Riska, C., Klockars, M. \& Selroos, O. (1983) N. Engi. J. Med. 308, 283-284.

8. Boomsma, F., Michiels, J. J., Prins, E., Abels, J. \& Schalekamp, M. A. D. H. (1983) Br. Med. J. 286, 1106.

9. Yotsumoto, H., Imai, Y., Kuzuya, N., Uchimura. H. \& Matsuzaki, F. (1982) Ann. Intern. Med. 96, 326-328.

10. Borowsky, S. A., Lieberman, J., Strome, S. \& Sastre, A. (1982) Arch. Intern. Med. 142, 893-895.

11. Lieberman, J. \& Sastre, A. (1980) Ann. Intern. Med. 93, 825-826.

12. Rømer, F. K. \& Emmertsen, K. (1980) Br. J. Cancer 42 , 314-318.
13. Romer, F. K. (1981) Br. J. Cancer 43, 135-142.

14. Cushman, D. W. \& Cheung, H. S. (1971) Biochem. Pharmacol. 20, 1637-1648.

15. Boomsma, F., de Bruyn, J. H. B., Derkx, F. H. M. \& Schalekamp, M. A. D. H. (1981) Clin. Sci. 60, 491-498.

16. Friedland, J. \& Silverstein, E. (1976) Am. J. Clin. Pathol. 66, 416-424.

17. Carmel, A., Ehrlich-Rogozinsky, S. \& Yaron, A. (1979) Clin. Chim. Acta 93, 215-220.

18. Rohrbach, M. S. (1978) Anal. Biochem. 84, 272-276.

19. Kasahara, Y. \& Ashihara, Y. (1981) Clin. Chem. 27, 19221925.

20. Hurst, P. L. \& Lovell-Smith, C. J. (1981) Clin. Chem. 27, 2048-2052.

21. Kwarts, E., Beukenveld. G. \& Gazendam, J. (1982) Ann. Clin. Biochem. 19, 227-232.

22. Chiknas, S. G. (1979) Clin. Chem. 25, 1259-1262.

23. Neels, H. M., Scharpé, S. L., van Sande, M. E., Verkerk, R. M. \& Van Acker, K. J. (1982) Clin. Chem. 2S. 1352-1355.

24. Cornbleet, P. J. \& Gochman, N. (1979) Clin. Chem. 25. 432-438.

25. Unpublished results of Fujizoki Pharmaceutical Co., Tokyo. Japan.
Dr. F. Boomsma

Dept. of Internal Med. I

Room P434

University Hospital Dijkzigt

Dr. Molewaterplein 40

NL-3015 GD Rotterdam 
1

-

\section{。}

;

. 